\title{
Sikker utredning av sjeldne urinveisinfeksjoner
}

Lundeby og medarbeidere redegjør for utredning av en sjelden form for urinveisinfeksjon hos en kvinne i 60-årene. Hun gjennomgikk flere CT-undersøkelser, cystografi, retrograd pyelografi, cystoskopi og to ganger ureterorenoskopi før endelig diagnose ble stilt. Som komplikasjon til ureterorenoskopi fikk hun urosepsis.

Pasienten ble henvist til urolog på grunn av residiverende urinveisinfeksjoner og hematuri. Utredning av urinveisinfeksjoner hos urolog omfatter normalt en kartlegging av vannlatingsmønster med miksjonsliste, undersøkelse av urinstrøm, måling av resturin og dyrkningsprøve. Ved cystoskopi og røntgenundersøkelse ser man etter fremmedlegemer og avløpshinder. Utredning av hematuri omfatter cystoskopi, kontrastundersøkelse av øvre urinveier og urincytologi.

En god anamnese har meget stor prediktiv verdi ved diagnostikk av urinveisinfeksjoner. Residiverende infeksjoner gjennom mange år, langvarig diabetes, alkoholmisbruk og sigarettrøyking er risikofaktorer for emfysematøs cystitt og pyelonefritt. Ved fistel mellom blære og tarm er slim i urinen et vanlig symptom, hvilket denne pasienten ikke hadde.

Forut for enhver medisinsk prosedyre påhviler det pasientansvarlig lege å vurdere nytte og risiko for pasienten. Når det gjelder diagnostisk utbytte, er det lite sannsynlig at luft skulle bli transportert fra pancreas eller duodenum til nyrebekken og derfra til blæren hos en pasient som ikke har gjennomgått samtidig transplantasjon av pancreas og nyre. Når det gjelder risikoen for infeksjonskomplikasjoner, er prosedyrens kontaminasjonsgrad avgjørende $(1,2)$.

Det er vanlig å regne med fire kontaminasjonskategorier: ren, ren-forurenset, forurenset og skitten/infisert (2). Hos en pasient med langvarig sykehistorie med urinveisinfeksjoner kan det være vanskelig å finne en effektiv infeksjonsprofylakse, og de mest potente antibiotika bør reserveres for terapi av eventuelle alvorlige komplikasjoner $(3,4)$. Uten effektiv antibotikaprofylakse regnes risikoen for infeksjonskomplikasjoner å være henholdsvis opptil $5 \%, 10 \%, 15 \%$ og $40 \%$ for hver av kontaminasjonskategoriene. Den alvorligste komplikasjonen fra urinveiene er urosepsis, som har en dødelighet på 20-40\% avhengig av hvor mange kriterier for systemisk inflammatorisk respons-syndrom og flerorgansvikt (multiple organ dysfunction syndrome, MODS) som oppfylles (3) .

Lundebys pasientomtale illustrerer at det er viktig å ta opp en god anamnese og å vurdere nytte og risiko før kirurgiske inngrep. Diagnostikk av luft i urinveiene kan være en stor utfordring, men det er symptomatisk for dagens helsevesen at vi ofte benytter store ressurser til utredning av funn som er gjort ved avansert bildediagnostikk og som har usikker sammenheng med pasientens problem. En forutsetning for en adekvat utredning er at man har kjennskap til den mest sannsynlige diagnosen. Emfysematøs cystopyelonefritt er en tilstand som flere leger bør kjenne til.

\section{Truls E. Bjerklund Johansen}

tebj@ki.au.dk

Oslo Urologiske Universitetsklinikk

Truls E. Bjerklund Johansen (f. 1951) er spesialist i urologi, professor og overlege. Han er leder for seksjon for urinveisinfeksjoner i den europeiske urologforeningen.

Forfatter har fylt ut ICMJE-skjemaet og oppgir ingen interessekonflikter.

\section{Litteratur}

1. Wagenlehner FME, Cek M, Naber KG et al. Epidemiology, treatment and prevention of healthcare-associated urinary tract infections. World J Urol 2012; 30: 59-67.

2. Grabe M, Botto $H$, Cek M et al. Preoperative assessment of the patient and risk factors for infectious complications and tentative classification of surgical field contamination of urological procedures. World J Urol 2012; 30: 39-50. http://dx.doi.org/10.1007/s00345-011-0722-z

3. Grabe M, Bjerklund Johansen TE, Botto H et al. Guidelines on urological infections. Arnheim: European Association of Urology, 2012

4. Çek M, Tandogdu Z, Naber K et al. Antibiotic prophylaxis in urology departments, 2005-2010. Eur Urol 2013; 63: 386-94.

Mottatt 19.9. 2013, første revisjon innsendt 5.11. 2013, godkjent 13.11. 2013. Redaktør: Sigurd Høye.

Engelsk oversettelse på www.tidsskriftet.no 